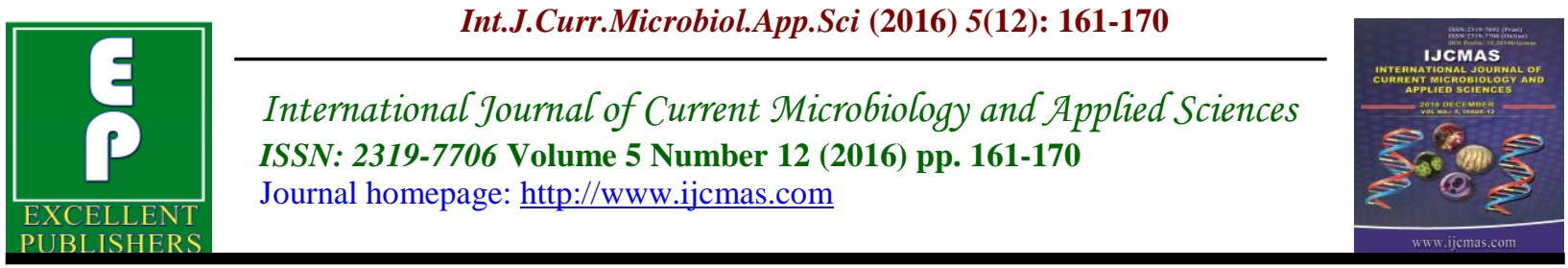

Original Research Article

http://dx.doi.org/10.20546/ijcmas.2016.512.018

\title{
Seed-Borne Fungi Associated with Rice Seeds Varieties in Bongor, Chad Republic
}

\author{
Serferbe Signaboubo ${ }^{1}$, G.R. Tsopmbeng Noumbo ${ }^{1}$ and Kuiate Jules Roger ${ }^{2}$ \\ ${ }^{1}$ Laboratory of Applied Botany, University of Dschang, Box 67 Dschang, Cameroon \\ ${ }^{2}$ Laboratory of Microbiology and Antimicrobial substances, University of Dschang, \\ Box 67 Dschang, Cameroon \\ *Corresponding author
}

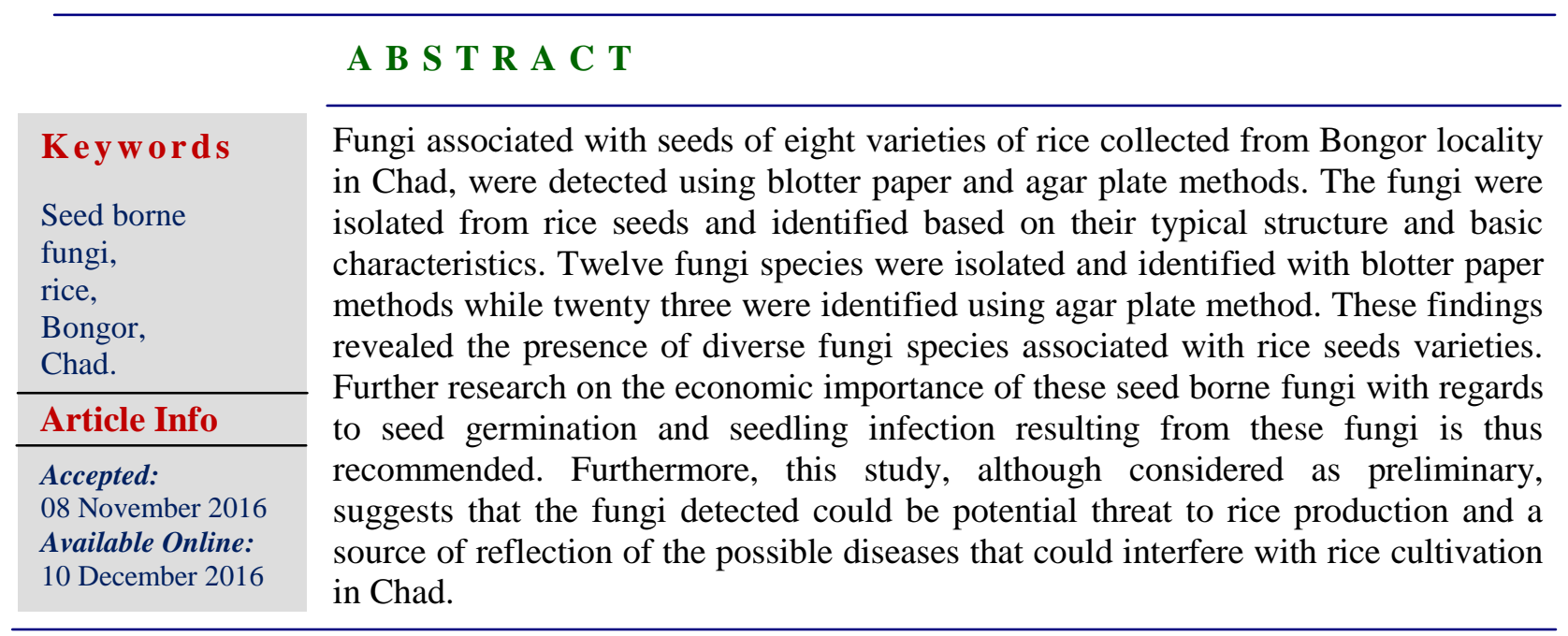

\section{Introduction}

Rice (Oryzae sativa L.) belongs to family Poaceae with two domesticated species of genus Oryzae. Oryzae sativa originates from tropical and subtropical southern Asia, while the African rice, Oryzae glaberrima, originates from West Africa (Renato et al., 2008; Habib et al., 2012). The crop is one of the most important food crops in the world which forms the staple diet of about 2.7 billons people and has become a commodity of strategic significance across many African countries (ICAR, 2006). It is also considered as the second most important cereal in the world, which provides about 95 $\%$ of food requirements of the world population (Juliano, 1993; Boumas, 1985). Produced in approximately 110 countries, including in variable degrees, in all west African countries, rice forms a major part of most people's diet in Africa after maize, sorghum, millet and to an extend in most developing parts of the world (Purseglove, 1988; Sakariyawo et al., 2013). In Chad, rice is grown either under upland or lowland conditions, with or without irrigation, for its seeds rich in starch, and is consumed as seeds, meal or in soups (Ngakou et al., 2013). As in most of African countries, rice has entered in the eating habits of Chadians for the past several years. It is therefore 
grown as a cash crop or is consumed locally in rural areas in the south (USAID, 2007). Its production is estimated at about $378.246 \mathrm{t}$ (ONDR, 2015). But the quantities produced are not enough to meet the national demand and the country continues to rely on importing rice from Asian countries. The low productivity is attributed to a number of important factors, which are seed-borne diseases, causing up to $50-80 \%$ yield losses depending on the crop susceptibility, disease severity and agro-ecological factors (Raymundo, 1980).

Seed borne diseases may not only introduce new pathogens or affect quantitatively and qualitatively the crop yield, but also contaminate permanently the soil (Anselme, 1981). Many of these diseases are of fungal origin (Nsemwa and Wolfhechel, 1999), transmitted mainly through use of infected seeds for planting. Studies carried out by (Biruma et al., 2003; Kanobe et al., 2004) showed a wide range of seed borne fungi pathogens on the farmers saved rice seeds, which they mainly relay on to propagate the next generation of crop. Most seed borne diseases caused by the fungi pathogens are disastrous as they may decrease seed germination, cause seed discolouration; produce toxins that may be injurious to man and domestic animals. Several seed borne fungi associated with rice seeds have been isolated in many countries including Nigeria (Suleiman and Omafe, 2013); Pakistan (Butt et al., 2011); Egypt (Madbouly et al., 2014), Bangladesh (Ora et al., 2011) and Cameroon (Nguefack, 2007). But to the best of our knowledge, no report is available on seed borne fungi status of rice in Chad. Increasing rice production and subsequent reduction of its international importation and endemic plant pathogens continue to be a challenge in safeguarding plant health in Chad. Therefore, early and accurate diagnoses and pathogen surveillance will give time for development and application of mitigation strategies. So, the assessment of seed health standard of rice is very important for farmers and food security as it is a first line approach in managing seed borne diseases of plants. Furthermore, the quality of planted seeds has a critical influence on the ability of crops to become established and to realize their full yield potential and value (McGee, 1995). The present study was carried out to detect and identify the fungi associated with rice seeds varieties from Bongor locality in Chad.

\section{Materials and Methods}

The experiment was carried out at the Laboratory of Phytopathology at the University of Dschang, Cameroun. Eight rice varieties were collected from Bongor rice Operating Station, Chad in December 2014. The samples were enclosed in paper bags with proper labelings, taken to the laboratory and kept in the refrigerator at $4 \pm$ $1{ }^{\circ} \mathrm{C}$ until used. Detailed information on varieties used is given in Table 1.

\section{Detection of fungi from seeds}

Rice seed varieties were assayed for the presence of fungi by the Standard Blotter Methods and Agar plate Methods following the rules of International Seed Testing Association (ISTA, 2001)

\section{Blotter paper methods}

Seeds were surface sterilised using sodium hypochlorite $\left(\mathrm{NaOCl}_{2}\right)$ diluted at $2 \%$ for 5 minutes. Four hundred seeds were used for each variety maintaining sixteen replications. Twenty five seeds were placed in three layers on moist blotting paper in each Petri dish. The Petri dishes were incubated at $24 \pm 2^{\circ} \mathrm{C}$ under alternating cycles of 12 hrs darkness and $12 \mathrm{hrs}$ light provided by white fluorescent tube (Mazda, 
T8 36W). Data regarding germination and infection were recorded 7 days after the incubation period and the results were recorded in percentages. Each of the incubated seeds was then examined for fungi growth under a stereo-microscope (20X). In fewer cases the fungi from the incubated seeds were transferred to PDA medium in Petri dishes aseptically and incubated under controlled temperature $\left(20 \pm 2^{\circ} \mathrm{C}\right)$ for $3-7$ days and then examined. Most of the associated pathogens were detected by observing their growth characteristics on the incubated seeds on Blotter paper following the keys outlined by Champion (1997), Mathur and Kongsdal (2003) and Warharm et al., (2008). Identification was also supplemented by microscopic examination of spores and fruiting bodies using a compound microscope and relevant books. The frequency of each fungus was determined from the percentage of the colonies of all the fungi developed as followed; F $=\mathrm{NF} / \mathrm{NT} \times 100$, where NF is the number of specific identified fungus and NT, the total number of detected fungi.

\section{Agar plate method}

In this method, two hundreds seeds were tested for each variety maintaining twenty replications. Surface sterilised seeds as above were plated (10 seeds/Petri dishes) on the potato dextrose agar (PDA) medium prepared from $250 \mathrm{~g}$ of Irish potatoes, $20 \mathrm{~g}$ of dextrose, and $20 \mathrm{~g}$ of agar-agar and 1000 $\mathrm{ml}$ of distilled water. The plated seeds were incubated for 7 days at $20 \pm 2^{\circ} \mathrm{C}$ in darkness. At the end of the incubation period, fungi developed from the seeds on the agar medium were examined and identified based on colony characteristics and morphology of fruiting bodies under a compound microscope. In the method, more than one type of fungi colonies were produced, and the identification was done on the most frequently occurring colony present in the Petri dishes and then the second most frequent and so on. Thereafter, the identification of different colonies was done visually and then under a stereomicroscope followed by an examination of the fruiting bodies under a compound microscope. Once the identification was done, the frequency of each fungus was determined as above.

Design of the Experiment: The experiment was conducted following Completely Randomized Design (CRD) with sixteen replications. The recorded data on percentage germination and fungi frequency were statistically analyzed using SPSS statistical package version 17 .

\section{Results and Discussion}

All the varieties tested were found to be infected by fungi but at different levels.

Using the Blotter method, the highest frequency of $11.7-19.8 \%$, was recorded with. Alternaria padwickii, followed by Curvilaria lunata, (5.9-14\%) Fusarium oxysporium (9.9-13.5\%) and Verticillium sp $(2-9.5 \%)$. However, their frequency of occurrence varied from one variety to another. Fusarium culmorum was present in varieties D3, TOX and WITA9 at low frequency of 2.4-4.6\% while Melanospora zamiae was found only in D1 variety $(3.8 \%)$ (Table 3). The germination percentage ranges from $87 \%$ to $100 \%$ with D1 recording the least and D4 and TOX the highest germination percentage. Infection percentage ranges from $14 \%$ to $23 \%$ for D1 and WITA9 and DA, respectively. Variety D4 with the highest germination percentage $(100 \%)$ recorded the highest infection percentage of $23 \%$ (Table 2).

In Agar plate method, among the fungi detected, ten were frequently isolated in 
seeds of the eight varieties of rice. These were Alternaria padwickii(8.5-17.5\%), Aspergillus flavus (2.7-9.5\%), Aspergillus niger (1.5-7.7\%), Curvularia lunata (5.1$10.1 \%)$, Curvularia oryzae(1.7-7.3\%), Fusarium oxysporium (5.6-13.6\%), Rhizoctonia solani (5.5-7.8\%), Rhizopus stolonifer $(0.2-7.7 \%)$, Tilletia caries $(0.8-$ $7.2 \%)$ and Verticilliumsp (3.6-6.9\%). The other species; Alternaria brassicae, Aspergillus Niger, Cladosporium sphaerospermum, C. pallescens, Epicoccum nigrum, Fusarium avenaceum, Fusarium culmoreum, Microdichium oryzae, Penicillium sp, Phoma lingan, Rhizopus stolonifer, Tilletia caries were found in low frequency.

The present study was focused on the survey of seed borne fungi associated with rice varieties form Bongor locality, Chad. Twelve fungal species were isolated and identified with blotter method while twenty were obtained by agar plate method. These results were in coherence with those of many research groups around the world (Imolehin, 1987; Khan et al., 1988, 2000; Kim and Lee, 1989; Odebunmi, 1989; Wahid et al., 1993; Javaid et al., 2002, Ibiam et al., 2006). Many of the isolated fungi have been reported to be associated with seeds of other crops (Tsopmbeng, 1994; Tsopmbeng and Fomengia, 2015). Some of them are also known to cause seed rot, decrease seed germination and cause pre and post damping off and seedling death (Al-kassam and Monawar, 2000).

Alternaria padwickii, Curvilaria lunata, Fusarium oxysporium, were found in high frequencies. This high frequency has been reported in previous studies on the seeds of rice in India (Archana and Prakash, 2013) and Pakistan (Khan, 2000; Javaid et al., 2002). Earlier observations reported the occurrence of Pyricularia oryzae, Alternaria alternata, A. padwickii, A. longissima, Curvularia oryzae, C. lunata, Drechslera oryzae, A. niger, Fusarium moniliforme, $F$. semitectum, $F$. oxysporum, $F$. solaniand species of Phoma, Cercospora, Chaetomium, Sclerotium, Penicillium, Myrothecium and Colletotrichum from seeds of rice varieties (Khan, 2000; Wahid et al., 2001; Javaid et al., 2002; Nguefack et al., 2007). In this study, Pyricularia oryzae, known for a long time as rice seed borne fungus (Manandadhar et al., 1998) was not isolated from any of the rice varieties, confirming the statement by Lamrani et al., (2013) who found that this fungus was less common on seeds. Aluko (1969) tested rice seed samples for seed borne fungi and indicated the scarcity of this fungus in Nigeria. Its absence in seed of rice varieties in Chad may indicate that blast caused by Pyricularia oryzae will be less frequent on rice grown in the field.

Alternaria padwickii was consistently isolated from rice seeds. According to Butt et al., (2011); Khan et al., (2000); Bhutta and Hussain (1998) and Khan et al., (1988), this fungus has a pathogenic role in rice seeds. Similarly Utobo et al., (2011) isolated Alternaria padwickii from stored rice grains and found that it was associated with high frequency.

According to Lamrani et al., (2013), Alternaria Padwickii colonizes a variety of seeds thus reducing the percentage germination and seed rot. Species of the genus Curvularia, in particular $C$. lunata has been reported to infect the embryo of the seeds therefore reducing the percentage germination of rice seeds (Imolehin, 1983; Bautista and Opina, 1991). Butt et al., (2011), Utobo et al., (2011) and Khanum and Khanzada (1989) reported Curvularia lunata in different rice varieties and labelled it as seed-borne. 
Table.1 Characteristics of different rice varieties

\begin{tabular}{|c|c|c|c|c|c|}
\hline Variety & $\begin{array}{l}\text { Cycle } \\
\text { (days) }\end{array}$ & Production system & $\begin{array}{c}\text { Mean yield } \\
\text { (t/ha) }\end{array}$ & Origin & $\begin{array}{c}\text { Shape of the } \\
\text { grains }\end{array}$ \\
\hline TOX & 90 & Rain fed and irrigated lowland & 5 & Imported & Long \\
\hline WITA9 & 120 & Rain fed and irrigated lowland & 10 & Imported & Long and thin \\
\hline $\mathrm{CH} 8$ & 120 & Rain fed and irrigated lowland & 6 & Imported & Long \\
\hline $\mathrm{CH} 3$ & 120 & Rain fed and irrigated lowland & 5 & Imported & Short and thin \\
\hline D6 & 120 & Rain fed and irrigated lowland & 5 & Local & Long \\
\hline D4 & 120 & Rain fed and irrigated lowland & 5 & Local & Long \\
\hline D3 & 120 & Rain fed and irrigated lowland & 5 & Local & Long \\
\hline D1 & 120 & Rain fed and irrigated lowland & 5 & Local & Long \\
\hline
\end{tabular}

Table.2 Percentage seed germination and seed-borne fungal infections of eight rice varieties collected from Bongor locality.

\begin{tabular}{lcc}
\hline Variety & Seed germination & Seed-borne fungi infections \\
\hline CH3 & $97 \pm 2^{\mathrm{a}^{*}}$ & $16 \pm 2^{\mathrm{ab}}$ \\
CH8 & $90 \pm 2^{\mathrm{b}}$ & $18 \pm 2^{\mathrm{ab}}$ \\
D1 & $87 \pm 2^{\mathrm{b}}$ & $14 \pm 2^{\mathrm{b}}$ \\
D3 & $96 \pm 2^{\mathrm{a}}$ & $22 \pm 2^{\mathrm{a}}$ \\
D4 & $100 \pm 2^{\mathrm{a}}$ & $23 \pm 2^{\mathrm{a}}$ \\
D6 & $100 \pm 2^{\mathrm{a}}$ & $16 \pm 2^{\mathrm{ab}}$ \\
TOX & $96,6 \pm 2^{\mathrm{a}}$ & $18 \pm 2^{\mathrm{ab}}$ \\
WITA9 & $96 \pm 2^{\mathrm{a}}$ & $14 \pm 2^{\mathrm{b}}$
\end{tabular}

*Means followed by the same letter(s) in each column are not significantly different by at $5 \%$ probability level using DMRT (Duncan Multiple Range Test). values were based on 400 seeds per variety.

Table.3 Percentage frequency of different fungi isolated on rice varieties by blotter method

\begin{tabular}{lcccccccc}
\hline & \multicolumn{7}{c}{ Rice seed varities } \\
\cline { 2 - 8 } Fungi isolated & CH3 & CH8 & D1 & D3 & D4 & D6 & TOX & WITA9 \\
\hline Alternaria alternata (Fr.) Keissl. & $2,9^{\text {de* }}$ & $5,8^{\mathrm{d}}$ & $2,7^{\mathrm{d}}$ & $0^{\mathrm{e}}$ & $0^{\mathrm{f}}$ & $4,6^{\mathrm{d}}$ & $5,9^{\mathrm{c}}$ & $2,9^{\mathrm{c}}$ \\
Alternaria padwickii (Ganguly) M. B. Ellis & $16,6^{\mathrm{a}}$ & $15,8^{\mathrm{a}}$ & $18,8^{\mathrm{a}}$ & $11,7^{\mathrm{ab}}$ & $17,8^{\mathrm{a}}$ & $17,4^{\mathrm{a}}$ & $16,9^{\mathrm{a}}$ & $19,8^{\mathrm{a}}$ \\
Aspergillus flavusLink. & $0^{\mathrm{e}}$ & $0^{\mathrm{e}}$ & $2,7^{\mathrm{d}}$ & $7,5^{\mathrm{bc}}$ & $5,3^{\mathrm{cd}}$ & $4,2^{\mathrm{d}}$ & $4,7^{\mathrm{d}}$ & $0^{\mathrm{e}}$ \\
Bipolaris hawaiiensis (M.B.Ellis) & $4,5^{\mathrm{d}}$ & $7,2^{\mathrm{c}}$ & $3,7^{\mathrm{d}}$ & $8,4^{\mathrm{b}}$ & $6,6^{\mathrm{c}}$ & $0^{\mathrm{e}}$ & $6,5^{\mathrm{c}}$ & $2,9^{\mathrm{de}}$ \\
Bipolaris oryzae (Breda de Haan) Shoem. & $7,5^{\mathrm{c}}$ & $11,6^{\mathrm{b}}$ & $8,9^{\mathrm{bc}}$ & $9,6^{\mathrm{b}}$ & $10,5^{\mathrm{b}}$ & $0^{\mathrm{e}}$ & $0^{\mathrm{de}}$ & $12,3^{\mathrm{b}}$ \\
Curvilaria lunata (Wakker) Boedijn & $7,5^{\mathrm{c}}$ & $5,9^{\mathrm{d}}$ & $7,7^{\mathrm{c}}$ & $11,7^{\mathrm{b}}$ & $14^{\mathrm{ab}}$ & $12,4^{\mathrm{b}}$ & $7,6^{\mathrm{c}}$ & $11,7^{\mathrm{bc}}$ \\
Curvilaria oryzae Bugnicourt & $4,4^{\mathrm{d}}$ & $0^{\mathrm{e}}$ & $9,5^{\mathrm{b}}$ & $0^{\mathrm{e}}$ & $0^{\mathrm{f}}$ & $13,6^{\mathrm{b}}$ & $13,8^{\mathrm{b}}$ & $0^{\mathrm{e}}$ \\
Fusarium culmorum (W.G. Sm.) Sace. & $0^{\mathrm{e}}$ & $0^{\mathrm{e}}$ & $0^{\mathrm{f}}$ & $2,4^{\mathrm{d}}$ & $0^{\mathrm{f}}$ & $0^{\mathrm{e}}$ & $4,6^{\mathrm{cd}}$ & $2,5^{\mathrm{b}}$ \\
Fusarium oxysporium Schltdl. & $13,5^{\mathrm{a}}$ & $12,2^{\mathrm{b}}$ & $10,8^{\mathrm{b}}$ & $13,2^{\mathrm{a}}$ & $12,1^{\mathrm{b}}$ & $10,9^{\mathrm{c}}$ & $12,7^{\mathrm{bc}}$ & $9,9^{\mathrm{c}}$ \\
Melanospora zamiae Corda & $0^{\mathrm{e}}$ & $0^{\mathrm{e}}$ & $3,8^{\mathrm{d}}$ & $0^{\mathrm{e}}$ & $0^{\mathrm{f}}$ & $0^{\mathrm{e}}$ & $0^{\mathrm{de}}$ & $0^{\mathrm{e}}$ \\
Rhizoctonia solani Kühn & $6^{\mathrm{bc}}$ & $7,3^{\mathrm{c}}$ & $5,7^{\mathrm{c}}$ & $2,8^{\mathrm{d}}$ & $0^{\mathrm{f}}$ & $4,5^{\mathrm{d}}$ & $5,6^{\mathrm{c}}$ & $4,4^{\mathrm{d}}$ \\
Verticillium sp & $9,5^{\mathrm{b}}$ & $3,9^{\mathrm{bc}}$ & $1,7^{\mathrm{e}}$ & $2^{\mathrm{d}}$ & $2,1^{\mathrm{e}}$ & $4,6^{\mathrm{d}}$ & $3,3^{\mathrm{d}}$ & $2,6^{\mathrm{de}}$ \\
\hline
\end{tabular}

Values with different letters within a column differ significantly at 5\% level of significance using DMRT (Duncan Multiple Range Test). Data present the mean of three replications. 
Table.4 Percentage frequency fungi isolated on rice varieties by agar plate method

\begin{tabular}{|c|c|c|c|c|c|c|c|c|}
\hline \multirow[b]{2}{*}{ Fungi isolated } & \multicolumn{8}{|c|}{ Rice seed varities } \\
\hline & $\mathrm{CH} 3$ & $\mathrm{CH} 8$ & D1 & D3 & D4 & D6 & TOX & WITA9 \\
\hline Alternaria alternata (Fr.) Keissl. & $5,1^{\mathrm{cd}}$ & $2,6^{\mathrm{e}}$ & $1,9^{\mathrm{g}}$ & $0^{\mathrm{h}}$ & $3,8^{\mathrm{e}}$ & $1,7^{\mathrm{f}}$ & $3,2^{\mathrm{f}}$ & $4,7^{\mathrm{f}}$ \\
\hline $\begin{array}{l}\text { Alternaria longissima Deighton \& } \\
\text { MacGarvie }\end{array}$ & $1,9^{\mathrm{d}}$ & $2,5^{\mathrm{e}}$ & $4,9^{\mathrm{d}}$ & $4,6^{\mathrm{d}}$ & $3,5^{\mathrm{e}}$ & $3,1^{\mathrm{d}}$ & $1,9^{\mathrm{d}}$ & $0^{\mathrm{j}}$ \\
\hline $\begin{array}{l}\text { Alternaria padwickii (Ganguly) M. B. } \\
\text { Ellis }\end{array}$ & $11,7^{\mathrm{a}}$ & $17,5^{\mathrm{a}}$ & $8,1^{\mathrm{b}}$ & $15,4^{\mathrm{a}}$ & $12,5^{\mathrm{a}}$ & $9,5^{\mathrm{a}}$ & $13,2^{\mathrm{a}}$ & $13,6^{\mathrm{a}}$ \\
\hline Aspergillus flavus Link. & $7,6^{\mathrm{c}}$ & $2,9^{\mathrm{e}}$ & $4,5^{\mathrm{d}}$ & $2,7^{\mathrm{f}}$ & $8,5^{\mathrm{c}}$ & $8,2^{\mathrm{ab}}$ & $9,5^{\mathrm{b}}$ & $7,8^{\mathrm{cd}}$ \\
\hline Aspergillus niger van Tiegh. & $5,2^{\mathrm{cd}}$ & $2,8^{\mathrm{e}}$ & $3,8^{\mathrm{e}}$ & $1,5^{\mathrm{fg}}$ & $2,7^{\mathrm{f}}$ & $2,5^{\mathrm{e}}$ & $7,7^{\mathrm{c}}$ & $5,9^{\mathrm{e}}$ \\
\hline Bipolaris hawaiiensis (M.B.Ellis) & $4,5^{\mathrm{d}}$ & $4,9^{\mathrm{d}}$ & $3^{\text {ef }}$ & $3,6^{\mathrm{e}}$ & $0^{\mathrm{h}}$ & $1,3^{\mathrm{f}}$ & $5,2^{\mathrm{d}}$ & $0^{\mathrm{j}}$ \\
\hline $\begin{array}{l}\text { Bipolaris oryzae (Breda de Haan) } \\
\text { Shoem }\end{array}$ & $5,1^{\mathrm{cd}}$ & $6,4^{\mathrm{c}}$ & $0^{\mathrm{h}}$ & $4,7^{\mathrm{d}}$ & $4,8^{\text {de }}$ & $0^{\mathrm{g}}$ & $0^{\mathrm{i}}$ & $3,8^{g}$ \\
\hline Bipolaris spicifera (Bainier) Subram. & $4,7^{\mathrm{d}}$ & $6,6^{\mathrm{c}}$ & $0,9^{\mathrm{gh}}$ & $1,6^{\mathrm{de}}$ & $2,4^{\mathrm{f}}$ & $2,9^{\mathrm{de}}$ & $4,4^{\mathrm{e}}$ & $0^{\mathrm{j}}$ \\
\hline Cercospora kikuchii (Mats. \& Tom) & $0^{\mathrm{f}}$ & $0^{\mathrm{f}}$ & $0^{\mathrm{h}}$ & $2,4^{\mathrm{f}}$ & $3,1^{\mathrm{e}}$ & $2,9^{\mathrm{de}}$ & $0^{\mathrm{i}}$ & $0^{\mathrm{j}}$ \\
\hline Cercospora oryzae & $0^{\mathrm{f}}$ & $0^{\mathrm{f}}$ & $5,5^{\mathrm{d}}$ & $0^{\mathrm{h}}$ & $0^{\mathrm{h}}$ & $0^{\mathrm{g}}$ & $0^{\mathrm{i}}$ & $3,8^{\mathrm{g}}$ \\
\hline Curvilaria lunata (Wakker) Boedijn & $8,1^{\mathrm{b}}$ & $5,1^{\mathrm{f}}$ & $2,8^{\mathrm{f}}$ & $7,2^{\mathrm{cd}}$ & $10,7^{\mathrm{b}}$ & $9,4^{\mathrm{a}}$ & $7,3^{\mathrm{c}}$ & $10,1^{\mathrm{b}}$ \\
\hline Curvilaria oryzae Bugnicourt & $5,6^{\mathrm{cd}}$ & $6,3^{\mathrm{c}}$ & $7,3^{\mathrm{c}}$ & $9,3^{\mathrm{c}}$ & $7,3^{\mathrm{c}}$ & $1,7^{\mathrm{f}}$ & $4,8^{\mathrm{e}}$ & $2,7^{\mathrm{h}}$ \\
\hline Epicoccum purpurescens Ehrenb. & $3,9^{\mathrm{d}}$ & $5,3^{\mathrm{b}}$ & $0^{\mathrm{h}}$ & $5,8^{\mathrm{d}}$ & $0^{\mathrm{h}}$ & $0^{\mathrm{g}}$ & $5,6^{\mathrm{d}}$ & $9,5^{\mathrm{c}}$ \\
\hline Fusarium culmorum (W.G.Sm.) Sace & $0^{\mathrm{f}}$ & $0^{\mathrm{f}}$ & $6,2^{\mathrm{c}}$ & $1,7^{\mathrm{fg}}$ & $0^{\mathrm{h}}$ & $6,9^{\mathrm{bc}}$ & $2,5^{\mathrm{g}}$ & $4,7^{\mathrm{f}}$ \\
\hline Fusarium moniliforme J. Sheld. & $0^{\mathrm{f}}$ & $0,4^{\mathrm{ef}}$ & $4,6^{\mathrm{d}}$ & $1,6^{\mathrm{fg}}$ & $0^{\mathrm{h}}$ & $0,7^{\mathrm{fg}}$ & $3,4^{\mathrm{f}}$ & $1,8^{\mathrm{c}}$ \\
\hline Fusarium oxysporium Schltdl. & $5,6^{\mathrm{cd}}$ & $12,8^{\mathrm{b}}$ & $13,6^{\mathrm{a}}$ & $10,7^{\mathrm{b}}$ & $11,1^{\mathrm{b}}$ & $7,1^{\mathrm{b}}$ & $12,3^{\mathrm{a}}$ & $14,5^{\mathrm{a}}$ \\
\hline Geotrichum sp & $0^{\mathrm{f}}$ & $1,4^{\mathrm{e}}$ & $1,3^{\mathrm{g}}$ & $0^{\mathrm{h}}$ & $0^{\mathrm{h}}$ & $1,5^{\mathrm{f}}$ & $1,1^{\mathrm{h}}$ & $0^{\mathrm{j}}$ \\
\hline Microdochium oryzae (Fr.) & $0,9^{\mathrm{e}}$ & $0^{\mathrm{f}}$ & $0^{\mathrm{h}}$ & $0^{\mathrm{h}}$ & $0^{\mathrm{h}}$ & $0^{\mathrm{g}}$ & $2,2^{\mathrm{g}}$ & $0^{\mathrm{j}}$ \\
\hline Phoma sp. Westend. & $0^{\mathrm{f}}$ & $0^{\mathrm{f}}$ & $0,7^{\mathrm{gh}}$ & $0^{\mathrm{h}}$ & $0^{\mathrm{h}}$ & $0^{\mathrm{g}}$ & $2,5^{\mathrm{g}}$ & $2,6^{\mathrm{h}}$ \\
\hline Rhizoctonia solani Kühn & $5,5^{\mathrm{cd}}$ & $7,8^{\mathrm{c}}$ & $7,2^{\mathrm{c}}$ & $3,6^{\mathrm{e}}$ & $4,5^{\mathrm{de}}$ & $6,1^{\mathrm{c}}$ & $4,4^{\mathrm{e}}$ & $3,6^{\mathrm{g}}$ \\
\hline Rhizopus stolonifer Ehrenb. & $7,7^{\mathrm{c}}$ & $1,7^{\mathrm{e}}$ & $3,9^{\mathrm{e}}$ & $0,2^{\mathrm{g}}$ & $1,6^{\mathrm{g}}$ & $3,9^{\mathrm{d}}$ & $5,6^{\mathrm{d}}$ & $6,4^{\mathrm{d}}$ \\
\hline Tilletia caries (DC.) Tulasne & $7,2^{\mathrm{c}}$ & $5,9^{\mathrm{cd}}$ & $2,6^{\mathrm{f}}$ & $5,4^{\mathrm{d}}$ & $2,5^{\mathrm{f}}$ & $3,7^{\mathrm{d}}$ & $0,8^{\text {hi }}$ & $1,1^{\mathrm{i}}$ \\
\hline Verticillium $s p$ & $4,9^{\mathrm{d}}$ & $5,2^{\mathrm{d}}$ & $3,6^{\mathrm{e}}$ & $3,6^{\mathrm{d}}$ & $4,4^{\mathrm{de}}$ & $6,9^{\mathrm{bc}}$ & $5,5^{\mathrm{d}}$ & $3,6^{\mathrm{g}}$ \\
\hline
\end{tabular}

Values with different letters within a column differ significantly at 5\% level of significance using DMRT (Duncan Multiple Range Test). Data present the mean of three replications.

Four hundred seeds were tested for each variety

According Duraiswamy and Mariappan (1980), the genus Curvilaria, is also involved in the discoloration of the rice seeds. As for Fusarium spp, they are major plant pathogens, and many are seedborne (Neergaard, 1979). F. oxysporum, an agent of Fusarium wilt of many hosts, was the most important species isolated. This fungus has a wide host range, including numerous formae speciales, some of which contain pathogenic races causing devastating wilt disease (Neergaard, 1979). Also, $F$. oxysporium has the ability to behave either as saprotrophe or parasite that attacks many plant species (Champion, 1997). Their presence in high frequency in rice seed varieties are not known and need to be investigated. In the present investigation, Fusarium spp, Curvularia lunata and Bipolaris spp were found more frequently 
with agar plate method whereas Alternaria padwickii, Fusarium oxysporium were found with the blotter paper method. The study also revealed that some fungi showed high frequency with agar plate method whereas some others were more frequent in blotter paper method. Ashfaq et al., (2015) evaluated the two methods and found that fungi like Penicillium globosum, Rhizoctonia sp., Phoma sp. were isolated in higher frequency from blotter paper method and Curvularia lunata and Drechslera sp. from agar plates. Khan et al., (1988) had also reported the blotter paper method as the most suitable method for detecting Alternaria alternata, A. tenuissima, Aspergillus niger, A. flavus, A. terreus, Chaetomium globosum and Curvularia lunata on rice seeds; whereas the agar plate method showed higher percent frequencies of isolation of Drechslera spp. and Curvularia spp. However, Agarwal et al., (1972) found out that the blotter paper method is a better method for the isolation of Drechslera oryzae and Alternaria padwickii than the agar plate method.

In conclusion, the present study reveals the presence of various fungi associated with rice seeds from Bongor locality in Chad and indicates the possibility of disease occurrence when such infected seeds are planted. Although the results of the present study may be considered preliminary, they suggest fungi associated with rice seeds are potential threat to its production. Research into the economic importance of these seed borne fungi with regards to seed germination and seedling infection resulting from these fungi is recommended for better seed health management.

\section{Acknowledgements}

The authors are grateful to the Chief of Bongor Station, Chad Republic for providing the seeds of rice varieties and the personnel of Phytopathology Laboratory of the University of Dschang, Cameroon for their assistance and other logistics for the experiment.

\section{References}

Al-Kassam, M.Y., and Manawar, M.N. 2000. Seed-borne fungi of some vegetable seeds in Gazan Province and their chemical control. Saudi J. Biol. Sci., 7 (2): 179-185.

Aluko. 1969. Relative prevalence of blast and brown leaf spot on upland rice in Nigeria. Plant Dis. Rep., 53, 875-877.

Anselme, C. 1981. The Importance in Cultivation of Pathogenic Organisms Transmitted by Seeds. Seed Sci. Technol., 9(3): 689-695.

Archana, B., and Prakash, H.S. 2013. Survey of seed-borne fungi associated with rice seeds in India. Int. J. Res. Pure and Appl. Microbiol., 3(1): 2529.

Ashfaq, M., Shaukat, M.S, Akhter, M., Haider, M.S., Mubashar, U., and Hussain, S.B. 2015. Comparison of fungal diversity of local and exotic rice (Oryza Sativa L.) Germplasm for their seed health. J. Animal and Plant, 25(5): 1349-1357.

Bautista, E.A., and Opina, O.S. 1991. Isolation, identification and pathogenicity test of seed borne fungi associated with cowpea seeds. Manila (Philippines). pp.1.

Bhutta, A.R., and Hussain, S.A. 1998. Seed borne fungi associated with rice seed lots. IRRN, 23(3): 26-27.

Biruma, M., Okori, P., Mudingotto, J., Edema, R., Tusiime, G., Mathur, S.B, and Adipala, E. 2003. Seed-borne fungi associated with farmer saved rice seed in Uganda and their effect on germination. MUARIK Bull., 6, 53-57. 
Boumas G. 1985. Grain Handling and Storage. Elsevier Science Publisher B.V., De Datta, S. K, p 9-10.

Butt, A.R., Yaseen, S.I., and Javaid, A. 2011. Seed borne mycoflora of stored rice grains and its chemical control. $J$. Animal Plant Sci., 21(2): 821-824.

Champion, R. 1997. Identifier les champignons transmis par les semences .Institut Nationale de la Recherche Agronomique.147, rue de l'Université, 75338, Paris Cedex, France, pp. 398.

Duraiswamy, V.S., and Mariappan, V. 1983. Rice grain discoloration. Intern. Rice Res. Newslett., 8 (3): 9-10.

Habib, A., Javed, N., Sahi, S.T., and Waheed, M. 2012. Detection of Seed Borne Mycoflora Harlow, Essex. New York, pp. 261-286.

Hannin, S., Hassikou, K., Benkirane, R., Ouazzani, A.T., and Douira, A. 2003. Etude de l'état sanitaire des semences du riz. Actes Institut Agronomique et Vétérinaire, 23(2-4): 127-134.

Ibiam, O.F.F., Umechuruba, C.I., and Arinze, A.E. 2006. Seed-borne fungi associated with seeds of rice (Oryzae sativa L.) in storage and from the field in Ohaozara and Onica Local Government areas of Ebonyi State. World J. Biotechnol., 7(1062): 1-72.

ICAR. (Indian Council for Agriculture Research). 2006. Handbook of Agriculture, New Delhi, Isolated From Stored Maize Seeds (Zea Mays (L.). Global J. Med. Plant Res., 1(1): 77-81. Imolehin, E.D. 1987. The rice seed multiplication centres in relation to seed-borne pathogens of rice: A case study of Ondo State Rice Multiplication Centres. Nigerian J. Plant Protection, 11, 37-42.

ISTA (International Seed Testing Association). 2001. International Rules for Seed Testing. Seed Sci
Technol., pp. 335.

Javaid, M.S., Wahid, A., Idrees, M., Gill, M.A., and Saleem, A. 2002. Seed mycoflora studies in rice. Pak. J. Phytopathol., 14, 132-134.

Juliano, B.O. 1993. Rice in Human Nutrition.FAO/IRRI. FAO Food and Nutrition Series N ${ }^{\circ}$ 26, FAO Rome.

Kanobe, C., Kawube, G., Biruma, M., Mudingotto, P.J., Edema, R., Okori, P., and Tusiime, G. 2004. La recherche agronomique.147, rue de l'Université, 75338, Paris Cedex. France, pp. 398.

Khan, S.A.J., Khanzada, A.K., Sultana, N., and Aslam, M. 1988. Evaluation of seed health testing techniques for the assessment of seed borne mycoflora of rice. Pak. J. Agri. Res., 9, 502-505.

Khan, T.Z., Gill, M.A., and Khan, M.G. 2000. Seed-borne fungi of rice from central Punjab and Their control. Pak. J. Phytopathol., 12: 12-14.

Khanam, M., and Khanzada, A.K. 1989. Seed borne fungal diseases of rice in Sindh, Pakistan. Pak. J. Agri. Res., 10, 302-305.

Kim, J.S, and Lee, Y.W. 1989. Identification of Aspergillus and Penicillium spp isolated from deteriorated rice. Korean J. Plants Pathol., 5, 389-91.

Lamrani, N., Elabdellaoui, F., Ouazzani, T.A., Benkirane, R., and Douira, A. 2013. Etude de la mycoflore des grains de trois variétés de riz et effet d'Alternaria padwickii (Ganguly) M.B. Ellis sur les grains pré-germés. Bulletin de l'Institut Scientifique, Rabat, Section Sciences de la Vie. 35, $1-7$.

Madbouly, A.K., Ibrahim, M.I.M., and Abdel-Wahhab, M.A. 2014. Efficacy of corn and rice seed-borne mycoflora in controlling aflatoxigenic Aspergillus flavus. Comunicata Scientiae, 5(2): 118-130. 
Manandadhar, H.K., Jorgensen, H.J.L., Smedegaard-Petersen, V., and Mathur, S.B. 1998. Seed-borne infection of rice by Pyricularia oryzae and its transmission to seedlings. Plant Dis., 82, 1093-1099.

Mathur, S.B., and Kongsdal, O. 2003. Common laboratory seed health testing methods for detecting fungi. Danish Government Institute of Seed Pathology for Developping Countries. Thorvaldsensvej 57, DK-1891 Frederiksberg C, Copenhagen, First edition, Denmark. pp. 425.

McGee, D.C. 1995. Epidemiological approach to disease management through seed technology. Annual Rev. Phytopathol., 33, 445-446.

Neergaard P. 1979. Seed pathology I, II. The Macmillan Press Ltd. London and Basingstoke 1- 1191.

Ngakou, A., Mbaiguinam, M., Nadjilom, Y., and Tokam, N. 2013. Agromorphological and Physical paddy seed attributed to Nigeria and local rice varities as affected by mycorrhizal inoculation and compost under upland conditions. Int. J. Agri. Sci. Res., 3(1): 43-62.

Nguefack, J., Nguikwie, S.K., Fotio, D., Dongmo, B., Leth, V., Nkengfack, A.E., and Amvam, Z.P.H. 2007. Fungicidal potential of essential oils and fractions from Cymbopogon citratus, Ocimum gratissimum and Thymus vulgaris to control Alternaria padwickii and Bipolaris oryzae, two seed-borne fungi of rice (Oryza sativa L.). J. Essential Oil Restitution, 19, 581-587.

Nsemwa L.T.H., and Wolffhechel H. 1999. Occurrence of seed-borne fungal pathogens in

Odebunmi, O.Y.K. 1989. Seed-borne pathogens of rice. Survival under experimental field conditions. Nigeria
J. Plant Protection, 11, 1-8.

ONDR (Office National de Développement Rural). 2015. Base des données de la production Céréalière de 2013/2014. Ministère de l'agriculture du Tchad, Ndjamena, Tchad. pp. 47.

Ora, N., Faruq A.N. Islam, M.T., Akhtar, N., and Rahman, M.M. 2011. Detection and of Seed borne from Some Cultivated hybrid rice varieties in Bangladesh. Middle East J. Scientific Res., 10(4): 482-488.

Purseglove, J.W. 1988. Tropical Crops: Monocotyledons. Longman house, Burnt Mill, Harlow, Essex. New York. pp: 261-286.

Renato, R., Ruaraidh, S.H., and Gabriel, R. 2008. Directives pour la régénération du riz. International Rice Research Institute (IRRI), Los Baños, Laguna, Philippines. pp. 12.

rice seeds from the Sourthern Highlands of Tanzania. African Crop Sci. J., 7(2): 217-222.

Sakariyawo, S., Kehinde, A., Okeleye, Michael, O., Dare Muftau, O., Atayese Akeem, A., Oyekanmi, Sunday, G., Aderibigbe, Christopher, J., Okonji Oluwaseun, G., Ogundaini Paul, A.S.S. 2013. Agronomic evaluation of some drought tolerant NERICA rice varieties to Arbuscular Mycorrhizae Fungi (AMF) inoculation in the rainforest transitory zone of Nigeria.

Suleiman M.N., and Omafe O.M. 2013. Activity Of Three Medicinal Plants On Fungi Isolated From Stored Maize Seeds (Zea Mays L.). Global J. Med. Plant Res., 1(1): 77-81.

Tsopmbeng, N.G. 1994. Seed-borne fungi in African Yam bean (Sphenostylis stenocarpa Horchstex. A. Rich Harms) and their responses to fungicidal seed-treatment. MSc. Thesis, University of Nigeria, Nsukka, Nigeria. pp. 96. 
Tsopmbeng, N.G., Fomengia, D.N. 2015. Fungi associated with seeds of huckleberry (Solanum scabrum Mill.) grown in the western highlands of Cameroon. J. Agri. Technol., 11(3): 791-801.

USAID (United States Agency for International Development). 2007. Food for peace. Chad Bellmon Analysis. pp. 37.

Utobo, E.B., Ogbodo, E.V., and Nwogbaga, A.C. 2011. Seed borne mycoflora associated with rice and their influence on growth at Abakaliki, Southeast Agro-Ecology, Nigeria. Libyan Agri. Res. Center J. Int., 2(2): 79-84.

Wahid, A.M., Saleem M.U, Khan, H, Tariq, A. Saleem. 1993. Seed-borne mycoflora of rice. J. Agri. Res., 31: 95-100.

Warharm, E.J., Butler, L.D., Sutton, B.C. 2008. Contrôle des semences de maïs et de blé. Guide de Laboratoire. International Maize and Wheat Improvement Center Lisboa Mexico. pp. 86.

\section{How to cite this article:}

Serferbe Signaboubo, G.R. Tsopmbeng Noumbo and Kuiate Jules Roger. 2016. Seed-Borne Fungi Associated with Rice Seeds Varieties in Bongor, Chad Republic. Int.J.Curr.Microbiol.App.Sci. 5(12): 161-170. doi: http://dx.doi.org/10.20546/ijcmas.2016.512.018 